\title{
Relationship between gene polymorphism and milk production traits in Teleorman Black Head sheep breed
}

\section{Relación entre el polimorfismo de genes y rasgos de producción de leche en la ovejas Teleorman cabeza negra}

\author{
Gras MA,* Ph.D, Pistol GC, Ph.D, Pelmus RS, Ph.D, Lazar C, Ph.D, Grosu H, Ph.D, Ghita E, Ph.D.
}

National Research-Development Institute for Biology and Nutrition, Animal Biology Laboratory, Calea Bucuresti No.1, Balotesti, Ilfov, 077015, Romania, Tel. number:0040726585870 Fax number: 0040213512080. *Correspondence: mihai.gras@ibna.ro,gras_mihai@yahoo.com

Received: November 2014; Accepted: May 2015.

\begin{abstract}
Objective. This study is a preliminary step of a larger national program aimed to develop a strategy for "in situ" preservation of Teleorman Black Head sheep population. In this paper we estimated the effect of $\beta$-lactoglobulin, casein and prolactin on some quantitative and qualitative milk traits in this local sheep population. Material and methods. Genotyping methodology included PCR for CSN3 ( $A$ and $B$ alleles) and PCR-RFLP for $L G B$ ( $A$ and $B$ alleles) and PRL ( $T$ and $C$ alleles), respectively. Repeated milking and milk composition analysis were used for the polymorphism effect estimation. Results. No association between CSN3 polymorphism and milk traits was found. Effect of $L G B$ on production traits was quite constant. Genotype $A A$ performed better than $B B$. $P R L$ marker effect showed small differences than $L G B$. Concerning milk, fat and protein yield, $A A$ genotype for $P R L$ had a smaller positive impact than $A A$ genotype for $\angle G B$. Regarding fat and protein content, $P R L$ showed a negative effect for $A A$ and positive for $B B$ genotype, respectively. Conclusions. Positive association between $L G B$ and milk yield and composition recommend this candidate gene like marker for a future MAS program. Although $P R L$ gene is also associated with an increased milk quantity, inverse response over milk composition must be considered in MAS strategy. Our study demonstrated that both $L G B$ and $P R L$ markers could became an advent of MAS utilization in Romanian dairy sheep breeding industry.
\end{abstract}

Key words: Biodiversity, gene, molecular markers, preservation, sequences (Source:AGROVOC).

\section{RESUMEN}

Objetivo. Este estudio es un paso preliminar de un programa nacional más amplio destinado a desarrollar una estrategia para la conservación "in situ"de la población de ovejas Cabeza Negra de Teleorman. En este trabajo se estimó el efecto de la $\beta$-lactoglobulina, caseína y prolactina en algunos rasgos cuantitativos y cualitativos de la leche en esta población de ovejas locales. Material y métodos. Metodología de PCR para genotipificación incluido CSN3 ( $A$ y $B$ alelos) y PCR-RFLP para $L G B$ ( $A$ y $B$ alelos) y $P R L$ ( $T$ y $C$ alelos). Análisis y composición de la leche de ordeños repetidos se utilizaron para estimación el efecto del polimorfismo. Resultados. No se encontró asociación entre el polimorfismo y la leche rasgos CSN3. Efecto de $L G B$ en los rasgos de producción era bastante constante. Genotipo $A A$ obtenido mejores resultados que $B B$. Efecto marcador $P R L$ mostró pequeñas diferencias que $L G B$. En cuanto a la leche grasa y proteína el genotipo $A A$ para $P R L$ tuvo un impacto positivo más pequeño que el genotipo $A A$ para $L G B$. En cuanto a contenido de grasa y proteína, $P R L$ mostró un efecto negativo para $A A$ y positivo para $B B$ genotipo. Conclusiones. $L a$ asociación positiva entre $L G B$ y la producción 
de leche y la composición recomienda este gen candidato como marcador para un futuro programa de MAS. Aunque gen $P R L$ también se asocia con un incrementoen la cantidad de leche, la respuesta inversa sobre composición de la leche debe ser considerado en la estrategia de MAS. Nuestro estudio demostró que los marcadores tanto $L G B$ y $P R L$ podrían venir a ser utilizados en MAS en la industria rumanade cría deovejas lecheras.

Palabras clave: Biodiversidad, genes, marcadores moleculares, preservación, secuencias (Fuente: AGROVOC).

\section{INTRODUCTION}

In Romania, sheep are managed in transhumance pastoralist system, using land resources otherwise useless for food production. Local sheep populations are well adapted to the harsh conditions in which they are grazed while still meeting the needs of their keepers. They can walk long distances while grazing, are resistant to diseases and parasites, survive through periods of feeding scarcity and other environmental stressors and have good prolificacy Carta et al (1). These adaptive traits and non-income ecosystem benefits, generally unappreciated, are major reasons to conserve this genetic resource is important. Teleorman Black Head is a dual purpose (milk and meat) local breed with male lambs commercialized for meat in spring, immediately after weaning and the milk used for cheese making. The breed is enlisted in the Domestic Animal Diversity Information System from FAO (http://dad.fao.org/). Selection in these sheep was performed mostly empirical and exclusively on own performance records, without a centralized selection goal. For this reason milk traits have large variability, with milk yield ranging between 160-210 liters, and fat percentage between $6.56-7.16 \%$ Pelmus et al (2).

"In situ" conservation, i.e. conservation of breed and the production system in which breed has evolved, is the overall objective of the project. Genetic improvement of milk production is needed if this population is to remain economically viable and, therefore, a critical step toward "in situ" preservation of the breed. Genetic improvement of milk production is needed to keep this breed economically viable. Small farms, absence of animal identification, pedigree structure and recording system, use of multiple rams and low heritability sex linked trait make implementation of a traditional breeding program impossible, but the implementation of MAS program should be feasible (3). Toward this objective, this preliminary study aimed to investigate the polymorphism of three genes known to be associated with milk yield and cheese production in several TBH sheep populations.

\section{INTRODUCCIÓN}

En Rumania, el manejo de las ovejas se realiza mediante el sistema de pastoreo trashumante en zonas donde la tierra no se puede utilizar para la producción de alimentos. Las poblaciones ovinas locales están bien adaptadas a las duras condiciones del terreno donde pastan y donde se satisfacen completamente las necesidades de sus pastores. Pueden recorrer largas distancias mientras se alimentan, son resistentes a enfermedades y parásitos, sobreviven a los períodos de escasez de alimento y a otros factores ambientales de estrés y además tienen buena prolificidad, Carta et al (1). Estas características adaptativas y beneficios ecosistémicos, que por lo general no se valoran, son las principales razones por las que es importante conservar este recurso genético. La raza local Cabeza Negra de Teleorman tiene un doble propósito (leche y carne); los corderos se comercializan para carne en la primavera inmediatamente después del destete y la leche se utiliza en la fabricación de queso. La raza está incluida en el Sistema de Información sobre la Diversidad de los Animales Domésticos de la FAO (http://dad.fao.org/). La selección de estas ovejas se realizó principalmente en forma empírica y exclusivamente de los propios registros de desempeño, sin un objetivo de selección centralizado. Por esta razón, las características lácteas tienen gran variabilidad, con una producción de leche que oscila entre 160 y 210 litros y un porcentaje de grasa entre 6.56 y $7.16 \%$. Pelmus et al (2).

El objetivo general del proyecto es la conservación "in situ", es decir, la conservación de la raza y el sistema de producción en el que la raza ha evolucionado. Se necesita de un mejoramiento genético de la producción de leche para que esta población siga siendo viable económicamente y, por tanto, un paso crítico hacia la conservación "in situ" de la raza. Es necesaria la mejora genética de la producción de leche para mantener esta raza económicamente viable. Las granjas pequeñas, la falta de identificación de los animales, el sistema de registro y la estructura de pedigrí, el uso de múltiples carneros y las características de baja heredabilidad ligada al sexo hacen imposible la implementación de un programa de cría tradicional, pero factible la puesta en práctica del Programa MAS (3). Con este 
Within the cheese industry, a special interest has been placed on the practical applications of the genetic markers in breed development programs and preservation strategies (4). For this purpose, substantial attention was attributed to the genetic structure of native sheep populations and the possible relationship between the genetic variants of milk protein genes and milk related traits (5).

B-lactoglobulin (LGB) is the major whey protein found in the milk of a number of species, accounting for approximate $75 \%$ of the albumin fractionencoded by $\angle G B$ gene. This gene is highly and specifically expressed in bovine mammary gland during lactation. One of the most extensively studied milk protein polymorphisms is the substitution of the amino acid Tyr20 with His in the LGB polypeptide (6) resulting in a saI restriction fragment length polymorphism which permits the genotyping of animals with a PCRRFLP method (7).

Caseins (CSN) are a family of milk proteins that exist in several molecular forms (as1-, as $2-, \beta-, \mathrm{K}$ casein) and are the main proteins present in milk (e.g. $80 \%$ in cow milk). Among these isoforms, kappa-casein (CSN3) was demonstrated to have an important role in improving milk yield in cattle. Genetic variability in the CSN3locushas been reported for several breeds, with allelic frequencies incorporated into studies on genetic diversity among breeds (8).

The lactogenic hormone prolactin ( $P R L)$, protein encoded by $P R L$ gene plays an important role in milk production (9). It was demonstrated that $P R L$ depletion in sheep was associated with reduction of milk secretion (8), suggesting that this hormone is a functional candidate gene for estimating of variations in milk yield. The $P R L$ gene is located in ovine chromosome 20, in a region where putative QTL for milk, fat, and protein yield (4) and for fat percentage have been identified (10). Also, $P R L$ gene was proposed to be used as a positional molecular marker associated with milk production and milk composition traits (9).

Starting from these data, the aim of our study was to evaluate the relationship between $L G B$, $C S N$ and $P R L$ gene polymorphism and the milk production traits in TBH breed using PCR-RFLP technique and general linear models.

\section{MATERIALS AND METHODS}

Animals and production traits. A total of 81 randomly selected ewes belonging to $\mathrm{TBH}$ breed objetivo, el presente estudio preliminar tuvo como objetivo investigar el polimorfismo de tres genes que se sabe están asociados con la producción de leche y la producción de queso en varias poblaciones de ovejas CNT (Cabeza Negra de Teleorman). Dentro de la industria del queso, se ha puesto especial interés en las aplicaciones prácticas de los marcadores genéticos en los programas de desarrollo de razas y las estrategias de conservación (4). Con este fin, se da una atención especial a la estructura genética de las poblaciones nativas de ovejas y la posible relación entre las variantes genéticas de los genes de las proteínas de la leche y las características relacionadas con la leche (5).

La B-lactoglobulina (LGB) es la principal proteína del suero que se encuentra en la leche de un número de especies, lo que representa aproximadamente el 75\% de la fracción de albúmina codificada por el gen LGB. Este gen se manifiesta elevada y específicamente en la glándula mamaria bovina durante la lactancia. Uno de los polimorfismos de la proteína de la leche mas extensamente estudiados es la sustitución del aminoácido Tyr20 con His en el polipéptido LGB (6), dando como resultado un polimorfismo de longitud de fragmentos de restricción SaI que permite la determinación del genotipo de los animales con un método RCP-PLFR (7).

Las caseínas (CSN) son una familia de proteínas lácteas que existen en varias formas moleculares (as1-, as2-, $\beta-$, K-caseína) y son las principales proteínas presentes en la leche (por ejemplo, $80 \%$ en la leche de vaca). Entre estas isoformas, la kappa-caseína (CSN3) demostró tener un papel importante en la mejora de la producción de leche en el ganado. Se reportó la variabilidad genética en el locus CSN3 para varias razas, con frecuencias alélicas incorporadas en los estudios sobre la diversidad genética entre razas (8).

La hormona prolactina lactogénica (PRL), proteína codificada por el gen $P R L$, juega un papel importante en la producción de leche (9). Se demostró que la disminución de PRL en las ovejas se asocia con una reducción de la secreción de la leche (8), lo que sugiere que esta hormona es un gen candidato funcional para estimar las variaciones de la producción lechera. El gen $P R L$ se encuentra en el cromosoma 20 de los ovinos, en una región donde se identificó un supuesto locus de caracteres cuantitativos (QTL por sus siglas en inglés) de la leche, producción de proteína (4) y porcentaje de grasa (10). También, se propuso utilizar el gen $P R L$ como un marcador molecular posicional asociado con la producción de leche y las características de composición láctea (9).

A partir de esta información, el objetivo de nuestro estudio consistió en evaluar la relación entre el 
from National Research Development Institute for Animal Biology and Nutrition (IBNA) flock were used for this study. Milk samples were obtained from each sheep at repeated intervals (14 days) between February - September 2011 and milk yield, fat and protein content were measured. Protein and fat content was quantified using Ecomilk analyzer. Blood samples were collected into a heparinized tube from the jugular vein of each sheep for DNA analysis.

Ethical aspects. Blood and milk samples were collected with veterinary assistance, and cared for procedure for sample collection, handle and preservation techniques, in accordance with the Romanian Law 206/2004 for handling and protection of animals used for experimental purposes. The study protocol was approved by the Ethical Committee of the National ResearchDevelopment Institute for Biology and Animal Nutrition, Balotesti, Romania.

Genomic DNA extraction. Genomic DNA was extracted from whole blood using a commercial kit (Wizard ${ }^{\circledR}$ Genomic DNA Purification Kit, Promega Corp., USA), according to manufacturer's recommendations.

PCR conditions. PCR was carried out in a total volume of $20 \mu \mathrm{l}$, containing 25-75 $\mathrm{ng}$ genomic DNA, $200 \mu \mathrm{M}$ dNTPs (Promega Corp., USA), 0.3 $\mu \mathrm{M}$ each primerand 1.25 units DNA polymerase (GoTaq Polymerase, Promega Corp., USA). PCR amplification was performed ina Corbett Research thermal cycler (Palm - Cycler, CG1-96 model). Thermal profile for $\angle G B$ and CSN3 genes amplification consisted from an initial denaturation step at $95^{\circ} \mathrm{C}$ for 10 minutes, followed by 35 amplification cycles of 30 seconds denaturation (at $95^{\circ} \mathrm{C}$ ), annealing for 30 seconds (at $60^{\circ} \mathrm{C}$ for $B L G$ and at $56^{\circ} \mathrm{C}$ for CSN3 genes), extension for 30 seconds at $70^{\circ} \mathrm{C}$ and one step of final extension at $70^{\circ} \mathrm{C}$ for 10 minutes.

The amplified 120 bp long PCR product of $L G B$ gene was digested with $R s a I$ restriction endonuclease (Promega Corp., USA), at $5 \mathrm{U} / 20 \mu \mathrm{l}$ concentration, for 3 hours at $37^{\circ} \mathrm{C}$ and separated on ethidium bromide-stained $2 \%$ agarose gel in TAE buffer.

Genotyping of the identified SNP located on CSN3 gene was performed using a set of primers combining one forward (CSN3-TC) and two reverse (CSN3-T and CSN3-C) primers, as shown in table 1.

Amplification protocol involved two reactions per sample containing SNP-TC/SNP-T and SNP-TC/ SNP-C primer pairs respectively, as described by Feligini cited by Giambra and Erhardt (5). This polimorfismo de los genes $L G B, C S N$ y $P R L$ y las características de producción de leche en la raza CNT utilizando la técnica RCP-PLFR y los modelos lineales generales.

\section{MATERIALES Y MÉTODOS}

Animales y características de producción. Para este estudio se utilizó un rebaño con un total de 81 ovejas pertenecientes a la raza CNT del Instituto Nacional de Desarrollo de la Investigación para Biología Animal y Nutrición (IBNA), las cuales fueron seleccionadas aleatoriamente. Se obtuvieron muestras de leche de cada oveja en intervalos repetidos (14 días) entre febrero y septiembre del año 2011 y se midió la producción de leche, grasa y el contenido proteínico. Los contenidos de proteínas y grasas se cuantificaron utilizando un analizador Ecomilk. Las muestras de sangre para el análisis de ADN se tomaron de la vena yugular de cada oveja en un tubo heparinizado.

Aspectos éticos. Las muestras de sangre y leche se recogieron con asistencia veterinaria y cumpliendo con los procedimientos para la toma de muestras, manejo y técnicas de conservación, de conformidad con la Ley rumana 206/2004 sobre el manejo y protección de los animales utilizados para experimentación. El protocolo de estudio fue aprobado por el Comité Ético del Instituto Nacional de Investigación y Desarrollo para la Biología y Nutrición Animal, Balotesti, de Rumania.

Extracción de ADN genómico. El ADN genómico se extrajo de la sangre total utilizando un kit comercial (Wizard $\AA$ Genomic DNA Purification Kit, Promega Corp., EE.UU.), de acuerdo con las recomendaciones del fabricante.

Condiciones RCP. La RCP se llevó a cabo en un volumen total de $20 \mu \mathrm{l}$, que contenía $25-75 \mathrm{ng}$ de ADN genómico, $200 \mu \mathrm{M}$ dNTPs (desoxirribonucleósidos trifosfato) (Promega Corp., EE.UU.), 0,3 $\mu \mathrm{M}$ de cada cebador y 1,25 unidades de ADN polimerasa (GoTaq Polymerase, Promega Corp., EE.UU.). La amplificación por RCP se realizó en un termociclador Corbett Research (Palm-Cycler, modelo CG1-96). El perfil térmico para la amplificación genética $L G B$ y CSN3 consistió de una etapa de desnaturalización inicial a $95^{\circ} \mathrm{C}$ durante 10 minutos, seguido por 30 segundos de desnaturalización de 35 ciclos de amplificación (a $\left.95^{\circ} \mathrm{C}\right)$, hibridación durante 30 segundos $\left(a 60^{\circ} \mathrm{C}\right.$ para los genes $B L G$ y a $56^{\circ} \mathrm{C}$ para los CSN3), la extensión por 30 segundos a $70^{\circ} \mathrm{C}$ y una etapa de extensión final a $70^{\circ} \mathrm{C}$ durante 10 minutos.

El producto RCP amplificado a $120 \mathrm{pb}$ (pares de base) del gen $L G B$ se digirió con la endonucleasa de restricción RsaI (Promega Corp., EE.UU.), en concentración $5 \mathrm{U} / 20 \mu \mathrm{l}$, durante 3 horas a $37^{\circ} \mathrm{C}$ y se separó con una tinción de bromuro de etidio del $2 \%$ 
Table 1. Nucleotide sequences of primers used for PCR-RFLP.

\begin{tabular}{|c|c|c|c|c|c|}
\hline Gene & Primer sequence $\left(5^{`} \rightarrow 3^{`}\right)$ & Orientation & $\begin{array}{c}\text { Primer length } \\
\text { (bp) }\end{array}$ & $\operatorname{Tm}\left({ }^{\circ} \mathrm{C}\right)$ & $\begin{array}{c}\text { Amplicon } \\
\text { length (bp) }\end{array}$ \\
\hline \multirow{2}{*}{ Prolactin $(P R L)$} & АССTCTCTTCGGAAATGTTCA & $\mathrm{FW}$ & 21 & 45 & \multirow{2}{*}{120} \\
\hline & CTGTTGGGCTTGCTCTITGTC & Rv & 21 & 49 & \\
\hline \multirow{3}{*}{ kappa-casein (CSN3) } & CTTCGATGACAAAATAGCCAA & $\mathrm{FW}(\mathrm{TC})$ & 21 & 43 & \multirow{2}{*}{$\begin{array}{c}85 \\
\text { (Tallele) }\end{array}$} \\
\hline & AATTGAGTCCATAACTAGGA & $\operatorname{Rv}(T)$ & 20 & 54 & \\
\hline & GGGGGGGGGGGGAATTGAGTCCATAACTAGGG & $R \vee(C)$ & 32 & 64 & $\begin{array}{c}97 \\
\text { (C allele) }\end{array}$ \\
\hline \multirow{2}{*}{$\beta$-lactoglobulin ( $L G B)$} & CAACTCAAGGTCCСTCTCCA & $\mathrm{Fw}$ & 20 & 62 & \multirow{2}{*}{2.500} \\
\hline & СTTCAGCTCCTCCACGTACA & Rv & 20 & 62 & \\
\hline
\end{tabular}

protocol allowed the two different PCR products (85 bp for $T$ allele and $97 \mathrm{bp}$ for $C$ allele) to be distinguished on $3 \%(w / v)$ agarose gel stained with ethidium bromide.

For $P R L$ gene, amplification was carried out using the protocol described by Staiger et al (8). A 2.5-kbp fragment spanning intron 2 of the ovine $P R L$ gene amplified was subsequently digested with HaeIII restriction enzyme (Promega Corp., USA). Products of digestion were visualized on a $3 \%$ agarose gelstained with ethidium bromide.

Statistical analysis. Hardy-Weinberg equilibrium was tested, for each gene, based on Feligini methodology, cited by Giambra (5).

Genotype effects are estimated at the QTL positions using Multiple Regression Least Square Method (11). The general model will be defined as:

$y_{i j}=\mu+h_{i}+m_{j}+e_{i j} \quad$ [1]

Where $y_{\ddot{u}}$ is the trait value of sheep $j$ in herd $i, \mu$ is overall mean, $h_{i}$ is fixed effect of herd i, $m_{j}$ is the effect of molecular marker $j$ and $e_{i j}$ is residual of the model. In matrix notation, model will became:

$y=\mathrm{X} b+\mathrm{M} u+e \quad[2]$

$y$ is the phenotypic values vector, $b$ is a vector of various fixed effects (like sex, farm, breed etc.), $u$ is a vector of marker effects (also fixed), $X$ and $M$ being incidence matrices for vectors $b$ and $u$. Marker effect was evaluated with the matrix model one previously described:

$\left[\begin{array}{cc}X^{\prime} X & X^{\prime} M \\ M^{\prime} X & M^{\prime} M+\frac{\sigma_{e}^{2}}{\sigma_{g}^{2}} I\end{array}\right]\left[\begin{array}{l}b \\ u\end{array}\right]=\left[\begin{array}{l}X^{\prime} Y \\ M^{\prime} Y\end{array}\right]$

Where $\frac{\sigma_{e}^{2}}{\sigma_{g}^{2}}$ is the variance ratio of the error and genetic effect in the model and $I$ is an identity matrix. We assume that just only half of genetic additive variance was captured by markers, then: $\sigma_{g}^{2}=\frac{\sigma_{a}^{2}}{2 L} \quad[4]$

$\sigma_{a}^{2}$ is genetic additive variance and $L$ representing number of markers. In this case, $\frac{\sigma_{e}^{2}}{\sigma_{g}^{2}} I$ term became de geles de agarosa en una solución amortiguadora TAE (Tris-acetato-EDTA).

La caracterización genética del PSN (polimorfismos de un solo nucleótido) identificado y localizado en el gen CSN3 se realizó utilizando un conjunto de bases que combinan una hacia adelante (CSN3-TC) y dos hacia atrás (CSN3-T y CSN3-C), como se muestra en la tabla 1.

El protocolo de amplificación incluyó dos reacciones por muestra que contienen PSN-TC / PSN-T y primer pares SNP-TC / SNP-C, respectivamente, según lo descrito por Feligini y citado por Giambra y Erhardt (5). Este protocolo permitió que los dos productos de PCR diferentes ( 85 pb para el alelo T y 97 pb para el alelo $\mathrm{C}$ ) se distinguieran en un gel de agarosa al $3 \%(w / v)$ teñido con bromuro de etidio.

Para el gen PRL, la amplificación se llevó a cabo utilizando el protocolo descrito por Staiger y colaboradores (8). Un fragmento de $2,5 \mathrm{kpb}$ que abarca el intrón 2 del gen ovino PRL amplificado fue digerido posteriormente con una enzima de restricción HaeIII (Promega Corp., EE.UU.). Los productos de la digestión se visualizaron en un gel de agarosa al 3\% gel en tinción con bromuro de etidio.

Análisis estadístico. Se probó el equilibrio de Hardy-Weinberg para cada gen, con base en la metodología de Feligini, citado por Giambra (5).

Se estimaron los efectos del genotipo en las posiciones de QTL utilizando el método de la regresión múltiple y mínimos cuadrados (11). El modelo general se define como:

$y_{i j}=\mu+h_{i}+m_{j}+e_{i j}$

Donde $y_{\ddot{y}}$ es el valor característico de ovejas j en el rebaño i, $\mu$ es la media global, $h_{i}$ es el efecto fijo de hato $i, m_{j}$ es el efecto del marcador molecular $j$ y $e_{i j}$ es residual del modelo. En notación matricial, el modelo se convertirá en:

$y=\mathrm{X} b+\mathrm{M} u+e[2]$

$y$ es el vector valores fenotípicos, $b$ es un vector de varios efectos fijos (como el sexo, la granja, la 
$\frac{2 L\left(1-h^{2}\right)}{h^{2}} I$ where studied trait heritability is $h^{2}$.

For marker codification we use 101 allele coding system, described by Strandén and Christensen (12). Value -1 was assigned to the homozygous genotype for the more frequent allele, 0 for the heterozygous genotype and 1 for less frequent allele. This codification describes a centered coding system with maximum mixing properties in the model. In comparison, we use a different codification for marker effect estimation ( 0 for allele absence, 1 and 2 respectively for allele number at each locus). A comparison between estimations was performed. Statistical analysis and marker effect estimation was performed in $\mathrm{R}$.

For marker effect estimation we use production traits heritability described by Ugarte cited by Pelmus (12): 0.19 for milk yield, 0.17 for fat yield, and 0.17 for fat content, 0.18 for protein yield and 0.47 for protein content.

\section{RESULTS}

In marker analysis the next steps were followed: gene polymorphism detection, estimation of the genotypic and allelic frequencies and evaluation of the genetic effect of analyzed markers.

LGB, CSN3 and PRL polymorphism detection. LGB: PCR amplification of ovine genomic DNA resulted in a $120 \mathrm{bp}$ fragment of the $L G B$ gene including exon 2 (Figure $1 \mathrm{~A}$ ).

Restriction fragment was identified after digestion with RsaI endonuclease; in particular two restriction sites (GT/AC) for allele $A$ and only one restriction site for allele $B$ were detected. Allele discrimination was based on size differentiation (bp) of $L G B$; the three different genotypes, $A A$ (66, 37 and 17 bp), $A B(103,66,37$ and 17 bp) and $B B$ (103 and $17 \mathrm{bp}$ ) were detected for Teleorman Black Head sheep (Figure 1B).

CSN3: Genotyping of the CSN3 gene was performed using the protocol described by Giambra and Erhardt (5). In our experiments two different PCR products with different length, $85 \mathrm{bp}$ for $T$ allele and $97 \mathrm{bp}$ for $C$ allele were identified (Figure 2).

PRL: A $2.5 \mathrm{kbp}$ fragment from $P R L$ gene was amplified successfully (Figure $3 \mathrm{~A}$ ).

Digestion with restriction enzyme HaeIII differentiated alleles $A$ and $B$. Allele $A$ contained 3 restriction sites for HaelII and resulted in 4 fragments of $1400,530,360$, and $150 \mathrm{bp}$, whereas the presence of an additional restriction raza, etc. ), $u$ es un vector de efectos de marcador (también fijo), X y M son matrices de incidencia para los vectores b y u. Se evaluó el efecto marcador con el modelo de matriz descrito anteriormente:

$\left[\begin{array}{cc}X^{\prime} X & X^{\prime} M \\ M^{\prime} X & M^{\prime} M+\frac{\sigma_{e}^{2}}{\sigma_{g}^{2}} I\end{array}\right]\left[\begin{array}{l}b \\ u\end{array}\right]=\left[\begin{array}{c}X^{\prime} Y \\ M^{\prime} Y\end{array}\right][3]$

Donde $\frac{\sigma_{e}^{2}}{\sigma_{g}^{2}}$ es la relación de la varianza del error y el efecto genético en el modelo e $I$ es una matriz de identidad. Suponemos que solo la mitad de la varianza genética aditiva fue capturada por los marcadores, entonces:

$\sigma_{g}^{2}=\frac{\sigma_{a}^{2}}{2 L}$

$\sigma_{a}^{2}$ es la varianza genética aditiva y $L$ representa el número de marcadores. En este caso, $\frac{\sigma_{e}^{2}}{\sigma_{g}^{2}} I$ el término $\frac{2 L\left(1-h^{2}\right)}{h^{2}}$ I cambia cuando las características de heredabilidad estudiadas corresponden a $h^{2}$.

Para la codificación del marcador utilizamos el sistema de codificación de 101 alelos, descritos por Stranden y Christensen (12). Se asignó el valor -1 al genotipo homocigoto para el alelo más frecuente, 0 para el genotipo heterocigoto y 1 para el alelo menos frecuente. Esta codificación describe un sistema centrado de codificación con las máximas propiedades de mezcla en el modelo. En comparación, utilizamos una codificación diferente para la estimación del efecto marcador (0 para la ausencia de alelos, 1 y 2 , respectivamente para el número de alelos en cada locus). Se realizó una comparación entre las estimaciones. El análisis estadístico y la estimación del efecto marcador se realizaron en $\mathrm{R}$.

Para la estimación del efecto marcador se utilizaron las características de la heredabilidad de producción descrita por Ugarte y citadas por Pelmus (12): 0.19 para producción lechera, 0.17 para la producción de grasa, 0.17 para el contenido de grasa, 0,18 para la producción de proteína y 0.47 para el contenido de proteína.

\section{RESULTADOS}

En el análisis del marcador se siguieron los siguientes pasos: detección de polimorfismo del gen, estimación genotípica y de las frecuencias alélicas y evaluación del efecto genético de los marcadores analizados.

Detección de los polimorfismos LGB, CSN3 y PRL. $L G B$ : ampliación RCP del ADN genómico ovino como producto de un fragmento $120 \mathrm{bp}$ del gen $L G B$ incluyendo exón 2 (Figura 1A). 
1A

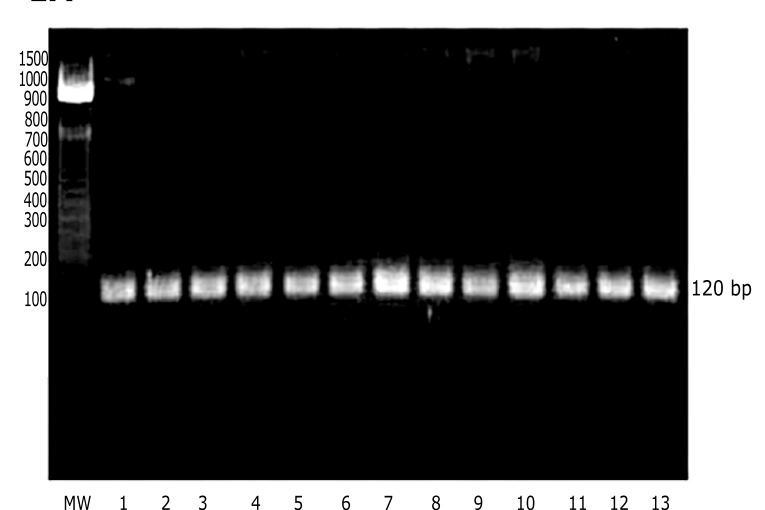

1B

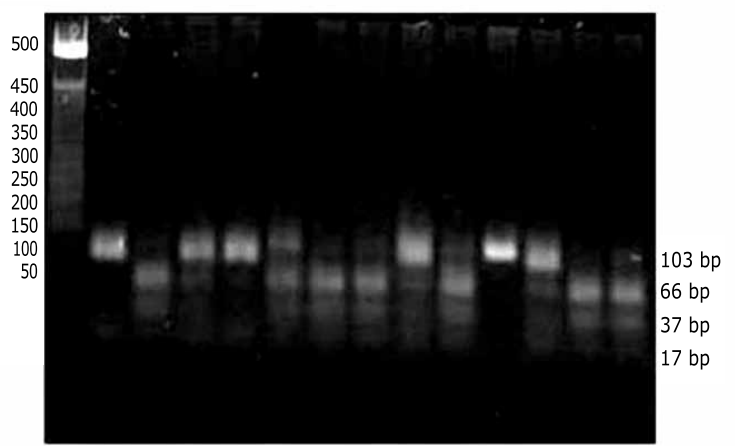

MW $B B \quad A A \quad A B$ BB $A B$ AA $A A$ BB AA $B B$ BB AA $A A$

Figure 1. $P C R$ amplification (1A) and RsaI digestion (1B) of the ovine LGB gene. PCR products of LGB gene were visualized on $2 \%(\mathrm{w} / \mathrm{v})$ agarose gel. Lane1: DNA ladder; lanes 2-14: ovine samples. RsaI RFPL products were identified on a $2 \%(\mathrm{w} / \mathrm{v})$ agarose gel. Lane1: DNA ladder; lanes 2, 5, 9, 11 and $12: B B$ genotype, lanes $3,7,8,10,13$ and 14: $A A$ genotype; lanes 4 and 6: $A B$ genotype.

site in the $B$ allele resulted in 5 fragments of $1400,510,360,150$, and 20 bp (Figure 3B).

Approx.30\% from genotyped animals show additional restriction sites that create a newer fragment of $700 \mathrm{bp}$ long.

Genotypic and allelicfrequencies for LGB, CSN3 and PRL genes. For $\angle G B$ gene a proportion of $49 \%$ of genotype $A A, 37 \%$ of $A B$ and $14 \%$ of $B B$ were found. The allelic frequency for $L G B$ gene was $68 \%$ for $A$ allele and $32 \%$ for $B$ allele.

Hardy-Weinberg equilibrium test returned the following observed and expected genotypes in our study (Table 2 ).

For $L G B$ gene, the TBH sheep population is in Hardy-Weinberg equilibrium that means their

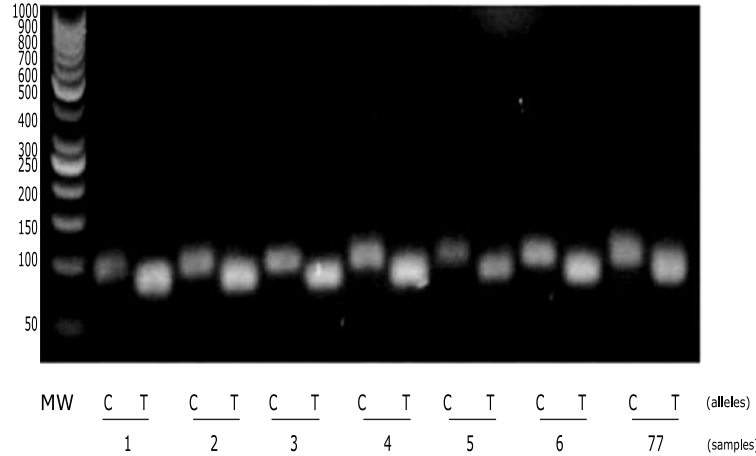

Figure 2. CNS3 PCR pattern for Teleorman Black Head sheep. $2 \%$ agarose gel electrophoresis was used for visualization of $C$ and $T$ alleles of ovine CSN3 gene. Lane 1: DNA ladder. Lanes 2-14: $C$ and $T$ alleles, respectively.

El fragmento de restricción se identificó después de la digestión con RsaI endonucleasa; en particular, se detectaron dos sitios de restricción (GT/AC) para el alelo $\mathrm{A}$ y un único sitio de restricción para el alelo B. La discriminación de alelos se basa en el tamaño de diferenciación ( $\mathrm{pb}$ ) de $\angle G B$; se detectaron tres genotipos diferentes, $A A(66,37$ y $17 \mathrm{pb}), A B(103$, $66,37$ y $17 \mathrm{pb})$ y $B B(103$ y $17 \mathrm{pb})$ para las ovejas Cabeza Negra de Teleorman (Figura 1B).

CSN3: La caracterización del genotipo del gen CSN3 se realizó utilizando el protocolo descrito por Giambra y Erhardt (5). En nuestros experimentos se identificaron dos productos de RCP diferentes con diferente longitud, $85 \mathrm{pb}$ para el alelo T y 97 pb para el alelo C (Figura 2).

$P R L:$ Se amplificó exitosamente un fragmento del gen $P R L$ a $2,5 \mathrm{kpb}$ (Figura 3A).

La digestión con enzima de restricción HaeIII diferenció los alelos $A$ y $B$. El alelo $A$ contenía 3 sitios de restricción para HaeIII y tuvo como resultado 4 fragmentos de $1400,530,360$, y 150 pb, mientras que la presencia de un sitio de restricción adicional en el alelo $B$ dio como resultado 5 fragmentos de $1.400,510,360,150$, y 20 pb (Figura 3B).

Aproximadamente el $30 \%$ de los animales a los que se les caracterizó el genotipo muestran sitios de restricción adicional que crean un nuevo fragmento de 700 pb de longitud.

Table 2. Observed and expected genotypes for $L G B$ gene.

\begin{tabular}{lcc}
\hline \multicolumn{1}{c}{ Genotype } & Observed & Expected \\
\hline$A A$ & 40 & 38 \\
$A B$ & 30 & 35 \\
$B B$ & 11 & 8 \\
$X^{2}$ at 2 df and 5\% significance & 3.85 & $3.85>1.95 *$ \\
calculated $\mathrm{X}^{2}$ & 1.95 &
\end{tabular}


3A

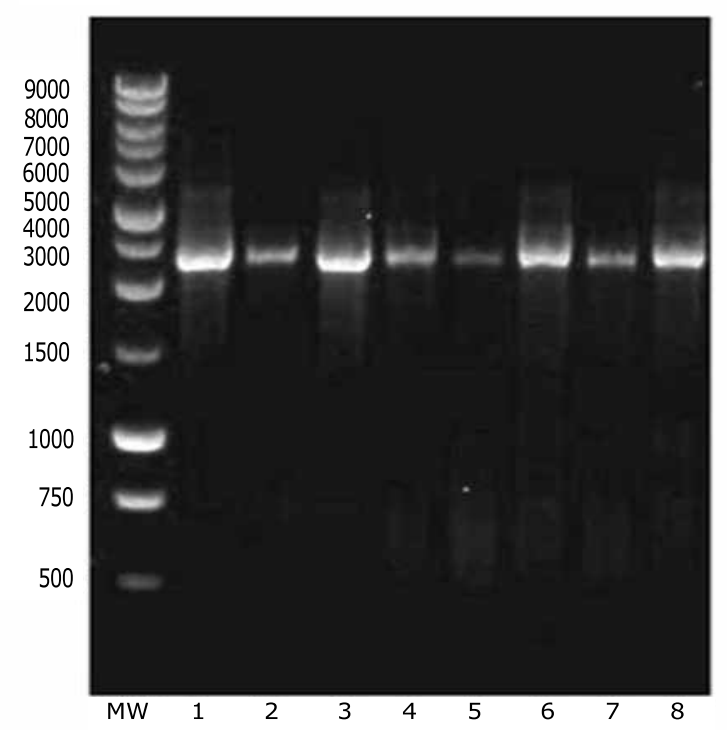

3B

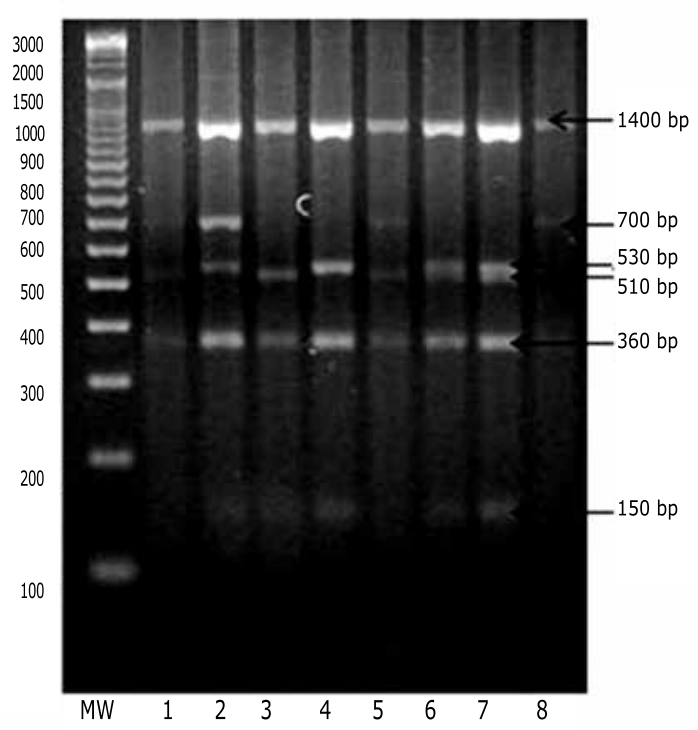

Figure 3. PCR amplification ( $3 A$ ) and HaeIII RFLP (3B) of the ovine PRL gene. PCR products of PRL gene were visualized on $2 \%(\mathrm{w} / \mathrm{v})$ agarose gel. Lane1: DNA ladder; lanes 2-8: ovine samples. HaeIII RFLP products of PRL gene were identified on a $3 \%(\mathrm{w} / \mathrm{v})$ agarose gel. Lane1: DNA ladder; lanes 2, 4, 6, 9: $B B$ genotype; lanes 3 and 5: $A A$ genotype; lanes 7 and 8: $A B$ genotype.

genotype was not affected by selection pressure for or against it. This aspect offer enough space for further implementation of selection program based on homozygosis on $L G B$ gene.

The genotypes for CSN3 gene showed a single $C T$ heterozygote genotype, without homozygote individuals. In our study, allelic frequency for casein gene was $50 \%$ for $C$ allele and $50 \%$ for $T$ allele. Comparison between observed and expected genotypes for Hardy-Weinberg equilibrium test is showed in table 3.

Table 3. Observed and expected genotypes for CSN3 gene.

\begin{tabular}{lcc}
\hline \multicolumn{1}{c}{ Genotype } & Observed & Expected \\
\hline$C C$ & 0 & 20 \\
$C T$ & 81 & 41 \\
$T T$ & 0 & 20 \\
$X^{2}$ at 2 df and 5\% significance & 3.85 & $3.85<81^{*}$ \\
calculated $\mathrm{X}^{2}$ & 81 & \\
\hline *null hypothesis is rejected & &
\end{tabular}

TBH sheep population is not in Hardy-Weinberg equilibrium for CSN3 gene, due to absence of homozygote genotypes.

The allelic frequencies for the genotypes of $P R L$ gene where $39 \%$ for $A A$ genotype, $28 \%$ for $A B$ and $33 \%$ for $B B$. Allele $A$ has $53 \%$ presence, meanwhile $B$ allele just $47 \%$.
Frecuencias alélicas y genotípicas para los genes LGB, CSN3 y PRL. Para el gen $L G B$ se encontró una proporción del $49 \%$ del genotipo $A A$, $37 \%$ del $A B$ y $14 \%$ de $B B$. La frecuencia alélica para el gen $L G B$ fue del $68 \%$ para el alelo $A$ y del $32 \%$ para el alelo $B$.

La prueba de equilibrio de Hardy-Weinberg produjo los siguientes genotipos observados y esperados en nuestro estudio (Tabla 2).

Para el gen $L G B$, la población ovina CNT está en equilibrio de Hardy-Weinberg, lo que significa que su genotipo no se vio afectado por la presión de la selección a favor o en contra de ella. Este aspecto ofrece espacio suficiente para seguir ejecutando el programa de selección con base en la homocigosis del gen $L G B$.

Los genotipos para el gen CSN3 mostraron un solo genotipo heterocigoto $C T$, sin individuos homocigotos. En nuestro estudio, la frecuencia alélica para el gen de la caseína fue del $50 \%$ para el alelo $C$ y $50 \%$ para el alelo T. En la Tabla 3 se muestra la comparación entre los genotipos observados y esperados para la prueba de equilibrio de Hardy-Weinberg.

La población ovina CNT no está en equilibrio de Hardy-Weinberg para el gen CSN3, debido a la ausencia de los genotipos homocigotos. 
Observed and expected genotypes for $P R L$ genotype (Table 4) show a lack of Hardy-Weinberg equilibrium. Hardy-Weinberg disequilibrium for $P R L$ gene pointed some empirical selection in behalf of $A A$ genotype and weighing against $A B$ and $B B$ genotypes.

Table 4. Observed and expected genotypes for $P R L$ gene.

\begin{tabular}{lcc}
\hline \hline \multicolumn{1}{c}{ Genotype } & Observed & Expected \\
\hline$A A$ & 32 & 23 \\
$A B$ & 23 & 40 \\
$B B$ & 26 & 18 \\
$X^{2}$ at 2 df and 5\% significance & 3.85 & $3.85<8.6 *$ \\
calculated $\mathrm{X}^{2}$ & 8.6 & \\
\hline *null hypothesis is rejected & &
\end{tabular}

Genetic effect on milk production traits. Milk, fat and protein yield perform measured in this studied population (throughout 144 lactation days) at first lactation was lower than breed average $(60.71 \pm 31.75 \mathrm{~kg}$ milk, $4.84 \pm 2.61 \mathrm{~kg}$ fat and $3.42 \pm 1.8 \mathrm{~kg}$ protein), but fat and protein content $(7.97 \pm 1.13 \%$ fat and $5.61 \pm 0.27 \%$ protein) were on the breed level. This diminished production was correlated with a prolonged dry period.

In order to estimate the effect of $L G B, C S N 3$ and $P R L$ alleles on milk production traits, we used Multiple Regression Least Square Method for all QTLs.

Assuming a balanced effect of alleles, heterozygote effect is set to zero. In this case, CSN3 shows a null effect for all individuals. Effect of markers on homozygotic animals is described in table 5 .

Table 5. Effect of $L G B$ and $P R L$ homozygotic genotypes over studied traits estimated using balanced marker codification.

\begin{tabular}{|c|c|c|c|c|}
\hline \multirow{3}{*}{ Milk production traits } & \multicolumn{4}{|c|}{ Genotype } \\
\hline & \multicolumn{2}{|c|}{$L G B$} & \multicolumn{2}{|c|}{ PRL } \\
\hline & $\boldsymbol{A A}$ & $B B$ & $\boldsymbol{A A}$ & $B B$ \\
\hline Milk yield $(\mathrm{kg})$ & 3.23 & -3.23 & 1.81 & -1.81 \\
\hline Fat yield $(\mathrm{kg})$ & 0.30 & -0.30 & 0.12 & -0.12 \\
\hline Fat content $(\%)$ & 0.13 & -0.13 & -0.10 & 0.10 \\
\hline Protein yield $(\mathrm{kg})$ & 0.16 & -0.16 & 0.08 & -0.08 \\
\hline Protein content $(\%)$ & 0.02 & -0.02 & -0.06 & 0.06 \\
\hline
\end{tabular}

Effect of $L G B$ over production traits is quite constant. Genotype $A A$ performs better then genotypes $B B$.

$P R L$ marker effect showed small differences compared with $L G B$ gene effect. Concerning milk, fat and protein yield $A A$ genotype for $P R L$ had a smaller (also positive) impact than the same genotype identified for $L G B$ gene. Regarding fat and protein content, $P R L$ showed a reversed effect, negative for $A A$ genotype and positive for $B B$ genotype, respectively.
Las frecuencias alélicas para los genotipos del gen $P R L$ donde el 39\% corresponde al genotipo $A A, 28 \%$ al $A B$ y $33 \%$ al $B B$. El alelo $A$ tiene una presencia del $53 \%$, por su parte alelo $B$ tiene una presencia tan solo del $47 \%$.

Los genotipos observados y esperados para los genotipos $P R L$ (Tabla 4) muestran la ausencia del equilibrio de Hardy-Weinberg. Este desequilibrio para el gen $P R L$ indica una selección empírica a favor del genotipo $A A$ y en contra de los genotipos $A B$ y $B B$.

Efecto genético sobre las características de la producción lechera. La leche, la grasa y el desempeño de la producción de proteína medidas en la población estudiada (a lo largo de 144 días de lactancia) en primera lactación fue inferior a la media de la raza $(60,71 \pm 31,75 \mathrm{~kg}$ de leche, 4,84 \pm $2,61 \mathrm{~kg}$ de grasa y $3,42 \pm 1,8 \mathrm{~kg}$ de proteína), pero el contenido de grasa y proteína $(7,97 \pm 1,13 \%$ de grasa y $5,61 \pm 0,27 \%$ de proteína) se encontraba en el nivel de la raza. Esta menor producción se correlaciona con un período de sequía prolongado.

Para estimar el efecto de los alelos $L G B, C S N 3$ y $P R L$ en las características de producción de leche, se utilizó la regresión múltiple mínimos cuadrados para todos los QTLs.

Suponiendo un efecto equilibrado de alelos, el efecto heterocigotico se establece en cero. En este caso, CSN3 no mostró ningún efecto para el total de individuos. El efecto de los marcadores sobre los animales homocigóticos se describe en la tabla 5.

El efecto de $L G B$ sobre las características de la producción es bastante constante. El comportamiento de los genotipos $A A$ es mejor que el de los genotipos $B B$.

El efecto del marcador $P R L$ mostró pequeñas diferencias en comparación con el efecto del gen $L G B$. En cuanto a la leche, grasa y producción de proteína, el genotipo $A A$ de la $P R L$ tuvo un impacto menor (también positivo) que el mismo genotipo identificado para gen $L G B$. En cuanto a la grasa y al contenido de proteína, $P R L$ mostró un efecto inverso, negativo para el genotipo $A A$ y positivo para el genotipo $B B$, respectivamente.

La prueba de chi cuadrado de Pearson aplicada a los resultados obtenidos con ambos sistemas de codificación no mostró diferencias entre las estimaciones.

En nuestro estudio, utilizamos una codificación diferente para la estimación del efecto marcador (0 para la ausencia de alelos, 1 y 2, respectivamente para el número de alelos en cada locus). Utilizando 
Pearson chi-squared test applied to the results obtained using both encoding systems showed no difference between estimates.

In our study, we use a different codification for marker effect estimation ( 0 for allele absence, 1 and 2 respectively for allele number at each locus). Using the described codification, in the same model and with the same parameter input, marker effect estimation was slightly higher but with similar pattern (Table 6).

Table 6. Effect of $L G B$ and $P R L$ homozygotic genotypes over studied traits estimated using 0,1 and 2 marker codification.

\begin{tabular}{lcccc}
\hline & \multicolumn{4}{c}{ Genotype } \\
\cline { 2 - 5 } Milk production traits & \multicolumn{2}{c}{ LGB } & \multicolumn{3}{c}{ PRL } \\
\cline { 2 - 5 } & AA & BB & BA \\
\hline Milk yield $(\mathrm{kg})$ & 4.88 & -4.88 & 2.67 & -2.67 \\
Fat yield $(\mathrm{kg})$ & 0.46 & -0.46 & 0.18 & -0.18 \\
Fat content $(\%)$ & 0.19 & -0.19 & -0.13 & 0.13 \\
Protein yield $(\mathrm{kg})$ & 0.25 & -0.25 & 0.12 & -0.12 \\
Protein content $(\%)$ & 0.03 & -0.03 & -0.07 & 0.07 \\
\hline
\end{tabular}

The estimated effect of $L G B$ is slightly superior (with $1.65 \mathrm{~kg}$ difference for milk yield and $0.01 \%$ for protein content) but, as a general rule, is the similar (along the production traits) with the one estimated with 101 allele encoding system. The same rule is applying for $P R L$ gene, but at a lower level, with difference of $0.86 \mathrm{~kg}$ for milk yield and $0.01 \%$ for protein content.

The differences observed in the estimation of marker effect using "101" and "each allele" encoding systems demonstrated the importance of codification in the design and implementation of the general linear model. For breeding value estimation, based on products like marker effect vector and marker assignation matrix is very important to use the same allele codification for all theindividuals used in the evaluation program.

\section{DISCUSSIONS}

A possible association between the genetic variants of the $L G B$ gene and milk-related traits was extensively studied by Mateescu and Thonney (4). On the other hand, Giambra and Erhardt (5) has demonstrated that a $\mathrm{T} \rightarrow \mathrm{C}$ nucleotide transversion in exon 2 of the $L G B$ gene can be detected using RsaI RFLP; also, this substitution results in the replacement of Tyr20 with His in the $\beta$-lactoglobulin polypeptide (8). Until now, the results of genetic studies regarding the allelic variants are conflicting, indicating no relationship between this SNP and milk yield or association la codificación descrita, en el mismo modelo y con los mismos parámetros de entrada, la estimación del efecto marcador fue ligeramente superior, pero con un patrón similar (Tabla 6).

El efecto estimado de $L G B$ es ligeramente superior (con $1.65 \mathrm{~kg}$ de diferencia para la producción lechera y $0.01 \%$ para el contenido de proteína) pero, como regla general, es similar (a lo largo de las características de producción) a lo estimado mediante el sistema de codificación de 101 alelos. La misma regla se aplica para el gen $P R L$, pero a un nivel inferior, con una diferencia de $0.86 \mathrm{~kg}$ para la producción lechera y $0.01 \%$ para el contenido de proteína.

Las diferencias observadas en la estimación del efecto marcador mediante los sistemas de codificación "101" y "cada alelo" demostraron la importancia de la codificación en el diseño e implementación del modelo lineal general. Para estimar el valor de la crianza, en base a productos como el vector efecto marcador y la matriz de asignación de marcadores, es muy importante utilizar la misma codificación de alelos para todos los individuos utilizados en el programa de evaluación.

\section{DISCUSIÓN}

Mateescu y Thonney (4) estudiaron ampliamente una posible relación entre las variantes genéticas del gen $L G B$ y las características relacionadas con la leche. Por otro lado, Giambra y Erhardt (5) demostraron que una transversión de nucleótidos $\mathrm{T} \rightarrow \mathrm{C}$ en el exón 2 del gen $L G B$ puede detectarse utilizando RsaI PLFR; por lo tanto, esta sustitución tiene como resultado el reemplazo de Tyr20 con His en los polipéptidos $\beta$-lactoglobulina (8). Hasta ahora los resultados de los estudios genéticos respecto a las variantes alélicas son contradictorios, indicando que no hay relación entre este PSN y la producción de leche o la asociación de cualquiera de los alelos $A$ o $B$ con las características de producción láctea. Por ejemplo, el genotipo $B B$ tiende a mostrar una mayor producción de leche en comparación con los genotipos $A A$ y $A B$ de las razas Massese y Sarda (8), mientras que Ramos y colaboradores (13) encontraron un resultado diferente para las razas Serra da Estrela y Merino, con una mayor producción de leche para los genotipos $A B$ y $B B$. Algunos estudios señalan la superioridad del alelo $A$. Staiger y colaboradores (8) asociaron el genotipo $A A$ con a una mayor producción lechera para las razas del Valle del Belice y Frisia Oriental. Las frecuencias genotípicas en el locus $L G B$ RsaI calculadas en el presente estudio fueron diferentes a las frecuencias reportadas por Wessels y colaboradores (14) en las ovejas de Frisia Oriental, donde el alelo B 
of either the $A$ or $B$ allele with milk production traits. For example, $B B$ genotype tends to show greater milk production compared with $A A$ and $A B$ genotype on Massese and Sardinian breeds (8), while Ramos et al (13) found a different result for Serra da Estrela and Merino breeds, with greater milk production for $A B$ and $B B$ genotypes. Some studies pointed out superiority of the $A$ allele. Staiger et al (8) associated $A A$ genotype with greater milk yield for Valle del Belice and East Friesian breeds. Genotypic frequencies at the $L G B$ $R$ saI locus calculated in the present study were different to the frequencies reported by Wessels et al (14) on East Friesian sheep, in which $B$ allele was predominant. In 2010, Staiger et al (8) reported very similar allelic frequencies, 0.69 and 0.31 for the $L G B$ RsaI polymorphism (alleles $A$ and $B$ ) on East Friesian breed, in comparison with 0.68 and 0.32 frequencies obtained in our study.

Giambra (5) observed an excess of heterozygote genotypes of $L G B$ in Pag sheep breeds. The $\mathrm{H}-\mathrm{W}$ disequilibrium shows, in author's opinion, a value of $A B$ genotype over $A A$ and $B B$ genotypes due to an empirical selection. The presence of $\mathrm{H}-\mathrm{W}$ equilibrium for $\angle G B$ gene in our studied population underlines the lack of selection pressure on animal genotypes. However, data regarding effect of $B L G$ gene on milk quality and quantity parameters show a positive effect, similarly with the effect found by Staiger et al (8) at Valle del Belice and East Friesian breeds.

In our study, CSN3 polymorphism showed equal frequencies ( 0.5 for both $C$ and $T$ alleles) similar with the frequencies found by Staiger et al (8) in East Friesian breed ( 0.51 and 0.49 , respectively). The present study did not find a significant effect of the CNS3 polymorphism on milk production. By contrast, Staiger et al (8) and Caravaca et al (15) reported a positive association between variants of CSN3 and milk traits in goats. On the other hand, any association between CSN3 locus and milk yield has not been reported in our study.

Despite the lack of CSN3 effect, the CSN3 genotyping need further investigation taking into account the number of individuals genotyped and DNA sequencing of $C$ and $T$ amplicons.

While the $L G B$ and CSN3 were intensely studied for their association with milk production traits, the effect of $P R L$ genotype was poorly investigated. Gene frequencies for $P R L$ HaeIII locus reported by Ramos et al (13), in the Serra da Estrela and Merino breeds showed that $A$ allele occurs more frequently than $B$ allele. Staiger et al (8) found a different occurrence of $B$ allele, more frequent than $A$. Serra da Estrela ewes (13) with $A A$ genotype determine a lower fue el predominante. En el año 2010, Staiger y colaboradores (8) reportaron frecuencias alélicas muy similares, 0.69 y 0.31 para el polimorfismo LGB RsaI (alelos A y B) de la raza Frisia Oriental en comparación con 0.68 y $0 . .32$ obtenidos en nuestro estudio.

Giambra (5) observó un exceso de genotipos heterocigotos de $L G B$ en ovejas de raza Pag. Los desequilibrios $\mathrm{H}-\mathrm{W}$ muestran, en la opinión del autor, un valor del genotipo $A B$ sobre el de los genotipos $A A$ y $B B$ debido a una selección empírica. La presencia del equilibrio $\mathrm{H}-\mathrm{W}$ en los genes $L G B$ en nuestra población de estudio destaca la falta de presión en la selección sobre los genotipos de los animales. Sin embargo, los datos sobre el efecto del gen BLG sobre la calidad de la leche y los parámetros de cantidad muestran un efecto positivo, de manera similar al efecto encontrado por Staiger y colaboradores (8) en las razas del Valle del Belice y Frisia oriental.

En nuestro estudio, el polimorfismo CSN3 mostró frecuencias iguales $(0,5$ para los alelos $C$ y $T)$, de manera similares a las frecuencias halladas por Staiger y colaboradores (8) en la raza Frisia Oriental ( 0.51 y 0.49 , respectivamente). En el presente estudio no se encontró ningún efecto significativo del polimorfismo CSN3 sobre la producción de leche. Por el contrario, Staiger y colaboradores (8) y Caravaca y colaboradores (15) reportaron una relación positiva entre las variantes de CSN3 y las características de la leche de cabra. Por otro lado, en nuestro estudio no se ha reportado ninguna relación entre el locus CSN3 y la producción lechera.

A pesar de la ausencia de efecto de la CSN3, la determinación del genotipo CSN3 requiere de mayor investigación teniendo en cuenta el número de individuos con genotipo ya determinado y la secuencia del ADN de los amplicones $C$ y $T$.

Mientras que $L G B$ y $C S N 3$ se estudiaron intensamente debido a su relación con las características de producción de leche, el efecto del genotipo $P R L$ se investigó muy poco. Las frecuencias genéticas para el locus PRL HaeIII reportadas por Ramos y colaboradores (13), en las razas Serra da Estrela y Merino, mostraron que el alelo $A$ se presenta con más frecuencia que el alelo $B$. Staiger y colaboradores (8) encontraron una incidencia diferente del alelo $B$, con mayor frecuencia que el $A$. Las ovejas Serra da Estrela (13) con el genotipo $A A$ presentan una producción de leche más baja en comparación con los genotipos $A B$ y $B B$. En nuestro estudio, el alelo $B$ del gen $P R L$ fue ligeramente superado por el alelo $A$. Además, el desequilibrio $\mathrm{H}-\mathrm{W}$ estimula los genotipos que contienen el alelo $A$. Los datos que se obtuvieron en nuestro estudio son totalmente diferentes a los obtenidos por Staiger y colaboradores (8) que reportaron que el 
milk yield compared with $A B$ and $B B$ genotypes. In our study, $B$ allele of $P R L$ gene is slightly outnumbered by $A$ allele. Also $\mathrm{H}-\mathrm{W}$ disequilibrium stimulates the genotypes containing Aallele. Data obtained in our study are totally different by those obtained by Staiger et al (8) who reported that $A$ allele has an increased frequency in East Friesian breed. This thing could point some empirical selection criteria that could leads to an excess in the use without knowledge of $A$ allele in selection programs. Like $L G B, A$ allele of the $P R L$ gene have a positive effect on milk production quantitative traits. Similar results are reported by Staiger et al (8) and Ramos et al (14). Like $L G B, A$ allele of the $P R L$ gene had a positive effect on milk production quantitative traits similarly with the results reported by Staiger et al (8) and Ramos et al (13) for East Friesian breed. Same allele produced a decreased of qualitative milk traits (fat and protein content). Approx 30\% of the genotyped animals presented additional restriction sites resulting in a new fragment. From this reason, other studies are necessary to assess the $P R L$ polymorphism and amplification fragment sequencing.

This preliminary study highlights the opportunity and necessity of the "in situ" preservation program for Teleorman Black Head sheep population. Using molecular biology techniques and mathematical modeling, our study demonstrates a strong association between genetic polymorphism and milk traits. Also, the identified markers might be used in a MAS program, together with the traditional breeding program. The further program evolution will permit the use of both programs (MAS and traditional) using Single Step Genomic BLUP evaluation method. Also, it must be taken into account the coherence and unity of the preservation program, and the evaluation of marker and production should be performed using the same protocol strategies.

Future supplementary studies for the validation of these results using an increased number of animals and the designing of a mating program in order to generate breeding rams with optimal genotypes for the two genes with positive effect are needed. Also, future extension of data obtained for TBH population to other sheep breeds from Romania will be taken into account.

In conclusions, positive association between $L G B$ and milk yield and composition, recommend this candidate gene, like marker for a future MAS program. Although $P R L$ gene is also associated with an increased milk quantity, the $P R L$ polymorphism investigated in our study could be taking into consideration in a MAS strategy. Teleorman Black Head sheep breed is the most alelo $A$ tiene un aumento de la frecuencia en la raza Frisia Oriental. Este aspecto podría señalar algunos criterios de selección empíricos que pueden conducir a un exceso en el uso sin conocimiento del alelo $A$ en los programas de selección. Al igual que $L G B$, el alelo $A$ del gen $P R L$ tiene un efecto positivo en las características cuantitativas de la producción lechera. Staiger y colaboradores (8) y Ramos y colaboradores (14) reportaron resultados similares. Al igual que $L G B$, el alelo $A$ del gen $P R L$ tuvo un efecto positivo en las características cuantitativas de la producción de leche, de manera similar a los resultados reportados por Staiger y colaboradores (8) y Ramos y colaboradores (13) para la raza Frisia Oriental. Los mismos alelos produjeron una disminución de las características cualitativas de la leche (contenido de grasa y proteína). Aproximadamente el $30 \%$ de los animales a los que se les determinó el genotipo presentan sitios de restricción adicionales que resultan en un nuevo fragmento. Por esta razón, es necesario realizar otros estudios con el fin de evaluar el polimorfismo $P R L$ y la amplificación de la secuencia de fragmentos.

Este estudio preliminar destaca la oportunidad y necesidad del programa de preservación "in situ" para la población ovina Cabeza Negra de Teleorman. Mediante el uso de técnicas de biología molecular y el modelado matemático, nuestro estudio demuestra una fuerte asociación entre el polimorfismo genético y las características de la leche. Igualmente, los marcadores identificados pueden ser utilizados en un programa MAS, junto con el programa de cría tradicional. La evolución adicional del programa permitirá el uso de ambos programas (MAS y tradicional) utilizando el método de evaluación Genómico BLUP de un solo paso. Por lo tanto, se debe tener en cuenta que la coherencia e integridad del programa de preservación y la evaluación del marcador y de la producción se deben realizar utilizando las mismas estrategias de protocolo.

En el futuro es necesario realizar estudios complementarios con el fin de validar estos resultados utilizando un mayor de número de animales y diseñar un programa de apareamiento para generar carneros reproductores con los genotipos óptimos de los dos genes con efecto positivo. De esta manera, se deberá considerar una futura ampliación de la información obtenida para la población de CNT a otras razas ovinas de Rumania.

En conclusión, la asociación positiva entre $L G B$ y la producción y la composición de la leche, recomienda este gen candidato, como un marcador para el futuro programa MAS. Aunque el gen $P R L$ también está asociado con al aumento de la cantidad de leche, el polimorfismo $P R L$ investigado en nuestro estudio podría ser tomado en cuenta en una estrategia MAS. La oveja Cabeza Negra de Teleorman es la raza más importante del sur 
important breed from the Southern Romania, exploiting very well poor nutritive forages from this part of the country; further studies are needed to extend the polymorphisms identified in present study to other sheep populations reared in Romania, both $\angle G B$ and $P R L$ markers could became an advent of MAS utilization in Romanian dairy sheep breeding industryin the future.

\section{Acknowledgements}

This work was financially supported from Projects PN 08938-01.01 and PN 0938-04.03, granted by the Romanian Ministry of Education. de Rumania, con una buena utilización de los forrajes con bajo nivel nutritivo de esta parte del país; se necesitan más estudios para ampliar los polimorfismos identificados en este trabajo a otras poblaciones de ovejas criadas en Rumania; en el futuro, los dos marcadores $L G B$ y $P R L$ se podrían convertir en el comienzo de la utilización del MAS en la industria rumana de cría de ovejas lecheras.

\section{Agradecimientos}

Este trabajo recibió apoyo financiero de los Proyectos PN 08938-01.01 y PN 0938-04.03, por parte del Ministerio de Educación de Rumania.

\section{REFERENCES}

1. Carta A, Casu S, Salaris S. Invited review: Current state of genetic improvement in dairy sheep. J Dairy Sci 2009; 92(12):5814-5833.

2. Pelmus RS, Pistol GC, Lazar C, Gras MA, Ghita E. Estimation of genetic parameters for milk traits in Romanian local sheep breed. Rev MVZ Córdoba 2014, 19(1):4033-4040.

3. Marshal K, Quiros-Campos C, van der Werf $\mathrm{JHJ}$, Kinghorn B. Marker-based selection within smallholder production systems in developing countries. Livest Sci 2011; 136(1):45-54.

4. Mateescu RG, Thonney M. Genetic mapping of quantitative trait loci for milk production in sheep. Anim Genet 2010; 41(5):460-6.

5. Giambra IJ, Erhardt G. Molecular genetic characterization of ovine CSN1S2 variants C and $D$ reveal further important variability within CSN1S2. Animal Genet 2012; 43(5):642-5.

6. Elyasi G, Shodja J, Nassiry MR, Tahmasebi A, Pirahary O, Javanmard A. Polymorphism of $\beta$-lactoglobulin gene in Iranian sheep breeds using PCR-RFLP. J Mol Genet 2010; 2(1):6-9.

7. Arora R, Bhatia S, Mishra BP, Sharma R, Pandey AK, Prakash B et al. Genetic polymorphism of the beta - lactoglobulin gene in native sheep from India. Biochem Genet 2010; 48(34):304-11.

8. Staiger EA, Thonney $\mathrm{ML}$, Buchanan JW, Rogers ER, Oltenacu PA, Mateescu RG. Effect of prolactin, $\beta$-lactoglobulin, and $\mathrm{K}$-casein genotype on milk yield in East Friesian sheep. J Dairy Sci 2010; 93(4):1736-1742.
9. Orford M, Tzamaloukas O, Papachristoforou C, Miltiadou D. A simplified PCR-based assay for the characterization of two prolactin variants that affect milk traits in sheep breeds. J Dairy Sci 2010; 93(12):5996-9.

10. Gutierrez-Gil B, El-Zarei MF, Alvarez L, Bayon $Y$, de la Fuente LF, San Primitivo $F$ et al. Quantitative trait loci underlying milk production traits in sheep. Anim Genet 2009; 40(4):423-34.

11. Gao H, Christensen OF, Madsen P, Nielsen US, Zhang Y, Lund MS, Su G. Comparison on genomic predictions using three GBLUP methods and two single-step blending methods in the Nordic Holstein population. Genet Sel Evol 2012; 44(1):8.

12. Strandén I, Christensen OF. Allele coding in genomic evaluation. Genet Sel Evol 2011; 43:25.

13. Ramos AM, Matos CAP, Russo-Almeida PA, Bettencourt CMV, Matos J, Martins A, et al. Candidate genes for milk production traits in Portuguese dairy sheep. Small Rumin Res 2009; 82(2-3):117-121.

14. Wessels G, Hamann H, Erhardt G, Distl O. Genotype effects of milk protein polymorphisms on milk production in East Friesian dairy sheep. Berl Munch Tierarztl Wochenschr 2004; 117(9-10):414-9.

15. Caravaca F, Carrizosa J, Urrutia B, Baena F, Jordana J, Amills M et al. Short communication: Effect of alphaS1-casein (CSN1S1) and kappacasein (CSN3) genotypes on milk composition in Murciano-Granadina goats. J Dairy Sci2009; 9(6):2960-4. 